\title{
Evaluation of Mitotic Figures and Cellular and Nuclear Morphometry of Various Histopathological Grades of Oral Squamous Cell Carcinoma Comparative study using crystal violet and Feulgen stains
}

Kashmira Kesarkar, Avinash Tamgadge, Treville Peirera, "Sandhya Tamgadge, Swati Gotmare, Pooja Kamat

$$
\begin{aligned}
& \text { تقييم الإنقسام التفتلي والبنية الخلوية والنووية لعدة درجات مرضية نسيجية من } \\
& \text { سرطان الحلاليا الحرشفية في الفم رئم } \\
& \text { دراسة مقارنة ما بين صبغتي البنفسج البلوري و صبغة الفلوسيه }
\end{aligned}
$$

كاشميرا كيساركار، أفيناش تامجادج، تريفيل بيريرا، سانديا تامجادج، سواتي جوتماري، بوجا كامات

ABSTRACT: Objectives: The objectives of this study were to quantitatively estimate the number of mitotic figures (MFs) and evaluate the cellular and nuclear features of various histological grades of oral squamous cell carcinoma (OSCC) using Feulgen and 1\% crystal violet stains. Methods: This case-control study took place at the Dr D. Y. Patil Dental College \& Hospital in Mumbai, Maharashtra, India, between June and December 2016. A total of 51 samples were retrieved from the hospital archives. Of these, 15 well-differentiated, 15 moderately-differentiated and six poorly-differentiated OSCC samples formed the case group while 15 samples of normal gingival mucosa constituted the control group. Each sample was dyed using Feulgen and 1\% crystal violet stains and the mitotic count, nuclear area (NA), cellular area (CA), nuclear perimeter $(\mathrm{NP})$, cellular perimeter $(\mathrm{CP})$ and nuclear-to-cytoplasmic $(\mathrm{N} / \mathrm{C})$ ratio was calculated using computeraided morphometry techniques. Results: The number of MFs visible per field was significantly higher in Feulgen-stained sections as compared to those stained with crystal violet $(P=0.050)$. In addition, the NA, NP, CA and CP values and $\mathrm{N} / \mathrm{C}$ ratios of samples in the experimental group increased significantly in accordance with an increase in OSCC grade $(P<0.001)$. Conclusion: The Feulgen stain is more reliable than $1 \%$ crystal violet in terms of the selective staining of MFs. Moreover, the findings of this study indicate that computer-based morphometric analysis is an effective tool for differentiating between various grades of OSCC.

Keywords: Crystal Violet; Feulgen Stain; Mitotic Index; Image Cytometry; Squamous Cell Carcinoma; Oral Cancers.

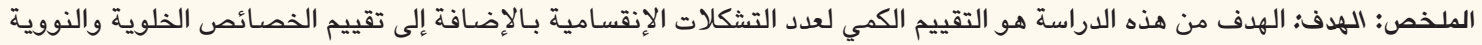

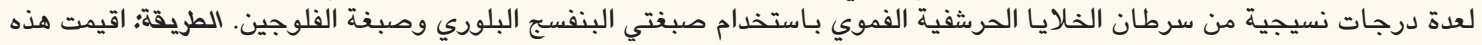

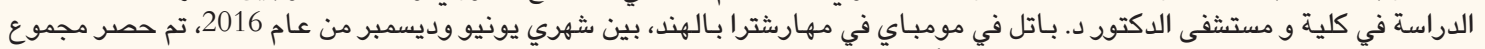

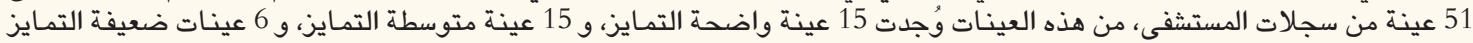

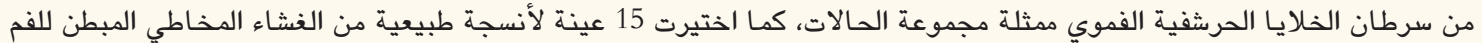

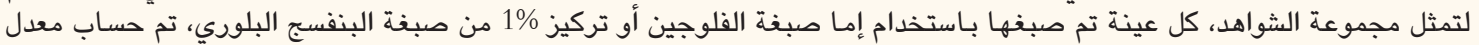

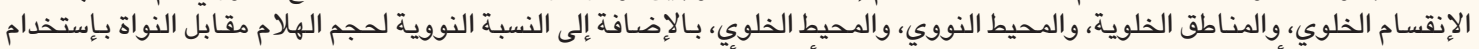

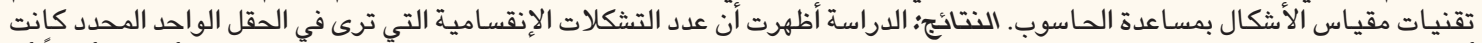

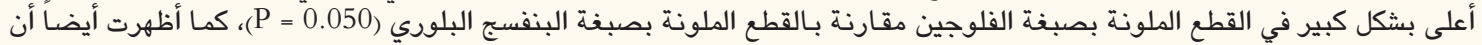

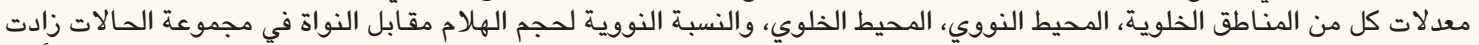

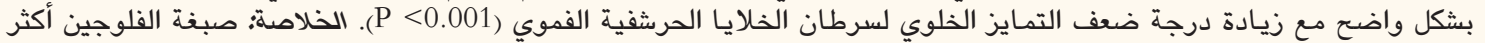

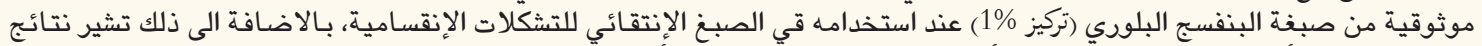

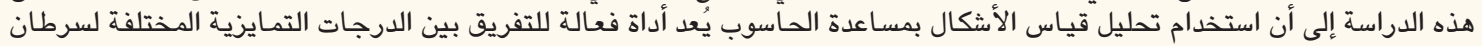
الخلايا الحرشفية الفموي.

الكلمات المفتاحية: صبغة البنفسج البلوري؛ صبغة الفلوجين؛ مؤثر الإنقسام؛ الصورة الخلوية؛ سرطان الخلايا الحرشفية؛ سرطان الفم.

\section{Advances In KNOWLedge}

Feulgen staining was found to provide a more reliable estimation of tumour aggressiveness and progression in comparison to crystal violet stains.

Moreover, there was a consistent increase in the mitotic count and cellular and nuclear measurements of oral squamous cell carcinoma cells according to histological grade. 
Application to Patient Care

Feulgen stains offer an objective basis for grading oral squamous cell carcinomas which may be otherwise missed in routine histopathological examinations, thereby aiding healthcare providers in the provision of appropriate treatment plans.

$\mathrm{C}$ ANCER DEVELOPS FROM a SERIES Of UNcontrolled cellular events known as atypia in which cellular and nuclear morphometric changes occur as a result of excessive alterations in DNA synthesis accompanied by proliferation and apoptosis. ${ }^{1}$ Mitosis is defined as a process of cell division wherein a single mother cell divides to produce two identical daughter cells; this process occurs in four distinct phases known as prophase, metaphase, anaphase and telophase. ${ }^{2}$ Excessive cell proliferation due to increased abnormal mitosis is the hallmark of cancerous and precancerous lesions. As such, quantitatively evaluating the number of cells undergoing mitosis-also known as mitotic figures (MFs) - can serve as a prognostic indicator for such lesions. ${ }^{2,3}$ Unfortunately, routine histochemical procedures cannot differentiate between pyknotic nuclei, apoptotic cells and MFs, posing a diagnostic problem. ${ }^{4}$ To date, light microscopy remains the gold standard for MF identification, among various other methods such as morphometry, immunohistochemistry, flow cytometry, DNA ploidy and nucleotide radiolabelling. ${ }^{5}$

Malignant cells also exhibit considerable variations in terms of their morphology and dimensions, including pleomorphism, nuclear hyperchromatism and increased nuclear-to-cytoplasmic (N/C) ratios. ${ }^{6}$ Various morphometric parameters including the shape and size of cells or cellular structures (i.e. the cellular area $[\mathrm{CA}]$, cellular perimeter $[\mathrm{CP}]$, nuclear area [NA] and nuclear perimeter $[\mathrm{NP}]$ ) as well as the $\mathrm{N} / \mathrm{C}$ ratio have proven useful in differentiating between normal tissues and potentially malignant disorders such as leukoplakia, lichen planus and oral squamous cell carcinoma (OSCC). ${ }^{7}$ Previous studies have deduced that computer-assisted image analysis allows for the assessment of large numbers of specimens with high reproducibility as well as sensitivity and accuracy rates exceeding 99\%. ${ }^{8,9}$ This method also allows for precise measurement of the size, shape, organisation and quantity of cells and their nuclei, while reducing interobserver discrepancies, thus increasing the reliability of accurate histopathological grading of the lesion. ${ }^{9}$

Special stains such as Feulgen and 1\% crystal violet stains which depend on the acid hydrolysis of DNA can be used to identify chromosomal material in cells and tissues. ${ }^{10}$ Previous studies have utilised haematoxylin and eosin (H\&E), Giemsa, crystal violet, toluidine blue and Feulgen stains to investigate chromatin patterns and identify MFs in brain, uterus and breast tissue. ${ }^{2,5,11}$ However, few studies have employed Feulgen stains to stain paraffin-embedded sections of oral dysplasia and OSCC cells. ${ }^{8,10}$ This study aimed to compare the number of MFs assessed quantitatively in normal mucosa and OSCC samples using Feulgen and $1 \%$ crystal violet stains. A secondary objective was to evaluate the mitotic count among various grades of OSCC. In addition, the study aimed to evaluate other nuclear and cellular morphometric variables among various grades of OSCC, including $\mathrm{CA}, \mathrm{CP}, \mathrm{NA}, \mathrm{NP}$ and $\mathrm{N} / \mathrm{C}$ ratio.

\section{Methods}

This case-control study was conducted between June and December 2016 in the Department of Oral \& Maxillofacial Pathology \& Microbiology at the Dr D. Y. Patil Dental College \& Hospital, Mumbai, Maharashtra, India. A total of 51 samples were retrieved from the hospital archives. The experimental group comprised 15 samples of well-differentiated, 15 samples of moderately-differentiated and six samples of poorlydifferentiated OSCC collected from surgical biopsies sent for diagnosis, while the control group consisted of 15 samples of normal gingival mucosa willingly donated by patients undergoing minor oral and periodontal surgeries. The gingival mucosa was chosen as the control tissue because the gingival epithelium is active and would thus be an adequate comparison for the highly active and proliferative epithelia of oral cancers and precancers. ${ }^{5}$ Two sections from each sample were prepared and stained with Feulgen and 1\% crystal violet stains as per established methods. ${ }^{12,13}$ Slides were observed under a Leica Microsystems LED Laboratory Microscope (Model DM1000, Meyer Instruments Inc., Houston, Texas, USA) and assessed using image analysis software (Version 3.8.0, Leica Microsystems Image Organizer software, Meyer Instruments Inc.). The sections were subsequently evaluated for MFs along with other cellular and nuclear features.

The four phases of mitosis were identified as follows. Cells lacking a nuclear membrane indicated that the prophase stage had begun; subsequently, the metaphase stage was characterised by condensed chromosomes forming clear hair-like extensions of nuclear material in either a clot or along a single equatorial plane. Anaphase was denoted by the clots beginning to separate into two separate parallel chromo- 


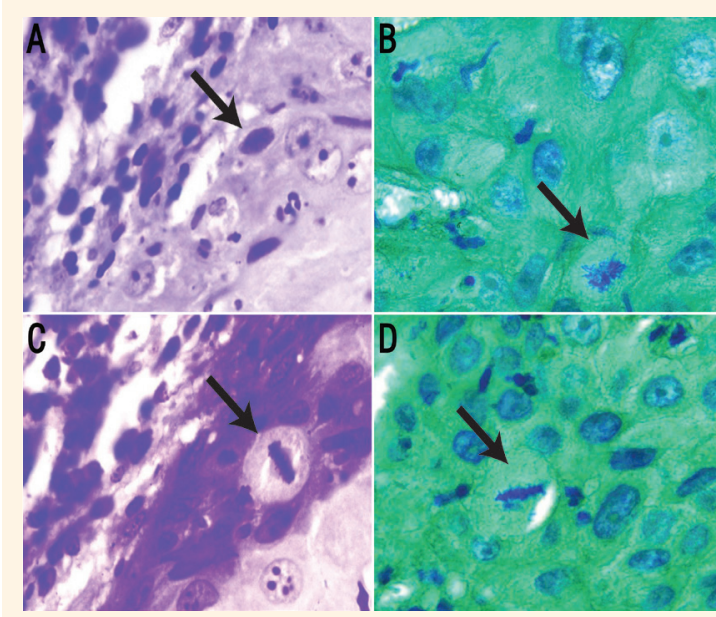

Figure 1: Paraffin-embedded oil immersion sections at x100 magnification showing the (A and B) prophase and $(\mathrm{C}$ and $\mathrm{D})$ metaphase stages of mitosis in welldifferentiated oral squamous cell carcinoma cells using $1 \%$ crystal violet and Feulgen stains, respectively.

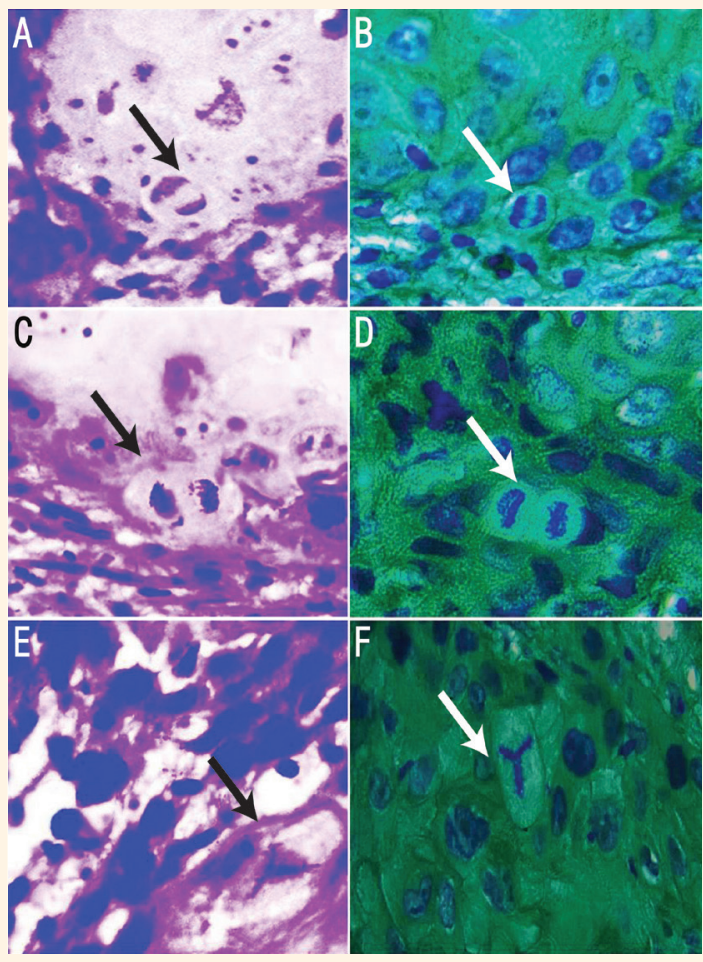

Figure 2: Paraffin-embedded oil immersion sections at x100 magnification showing the (A and B) anaphase and (C and D) telophase stages of mitosis and (E and F) tripolar mitosis in well-differentiated oral squamous cell carcinoma cells using 1\% crystal violet and Feulgen stains, respectively.

somes, while the movement of the chromosomes to separate poles of the cell signified the telophase stage. Each MF was identified as per criteria reported by Van Diest et al. ${ }^{1}$ The MFs were analysed at various magnifications and counted in 'step-ladder' fashion using an oculometer grid of 15 fields at x40 magnification. The entire stretch of the epithelium was
Table 1: Mean mitotic figure count using Feulgen and $1 \%$ crystal violet stains in samples of normal gingival mucosa and various grades of oral squamous cell carcinoma $(\mathrm{N}=51)$

$\begin{array}{lccc}\text { Stain } & \begin{array}{c}\text { Mean MF count } \\ \text { per field } \pm \text { SD }\end{array} & \text { T value } & \text { P value* } \\ \text { Feulgen } & 3.51 \pm 2.93 & 1.938 & 0.050 \\ \text { Crystal violet } & 2.47 \pm 2.47 & & \end{array}$

$M F=$ mitotic figure $; S D=$ standard deviation .

*Using an unpaired two-tailed Student's t-test.

searched for MFs, excluding areas of inflammation, necrosis, tissue folds and calcification.

After reviewing the number of MFs in the tissue sections, the samples were evaluated for nuclear and cellular morphometric features. The final image of the representative cells in the basal cell layer was captured at x10 magnification using the Leica Microsystems Image Organizer software (Meyer Instruments Inc.), avoiding areas of basal cell hyperplasia and overlapping cells. The outlines of the cells and nuclei were traced on a black and white monitor and the size of the cell and nucleus was calculated by measuring the area and perimeter of the outline. ${ }^{8}$ Afterwards, the cellular and nuclear outlines of 5-7 cells with the largest dimensions and the clearest outlines were traced. The CA, CP, NA and NP were then automatically calculated by the Leica Microsystems Image Organizer software (Meyer Instruments Inc.), based on the number of boundary pixels detected. The N/C ratio of the cell was calculated using the following formula: ${ }^{6}$

$$
\mathrm{N} / \mathrm{C} \text { ratio }=\frac{\mathrm{NA}}{\text { cytoplasmic area }-\mathrm{NA}}
$$

Differential and inferential statistical analyses were undertaken using the Statistical Package for the Social Sciences (SPSS), Version 20.0 (IBM Corp., Armonk, New York, USA) and Microsoft Excel, Version 2007 (Microsoft Inc., Redmond, Washington, USA). Continuous measurements were presented as means and standard deviations. The level of significance was set at $P \leq 0.050$. Continuous parameters were compared between two groups using an unpaired two-tailed Student's t-test, while comparisons between three or more groups were performed using an analysis of variance test which, if significant, was followed by a post hoc analysis.

Ethical approval for this study was obtained from the Institutional Review Board of the Dr D. Y. Patil Dental College \& Hospital (\#DYPUSOD/GS-OPSAT/28/2017). Written consent to collect oral samples was obtained from all donors in both the control and case groups. 
Table 2: Mean cellular area, cellular perimeter, nuclear area, nuclear perimeter and nuclear-to-cytoplasmic ratio of samples of normal gingival mucosa and various grades of oral squamous cell carcinoma $(\mathrm{N}=51)$

\begin{tabular}{|c|c|c|c|c|c|c|}
\hline Sample group & $\begin{array}{c}\text { Mean CA in } \\
\mathrm{mm}^{2} \pm \mathrm{SD}^{*}\end{array}$ & $\begin{array}{l}\text { Mean CP in } \\
\mathrm{mm}^{2} \pm \mathrm{SD}^{*}\end{array}$ & $\begin{array}{c}\text { Mean NA in } \\
\mathrm{mm}^{2} \pm \mathrm{SD}^{*}\end{array}$ & $\begin{array}{c}\text { Mean NP in } \\
\mathrm{mm}^{2} \pm \mathrm{SD}^{*}\end{array}$ & $\begin{array}{c}\text { Mean N/C } \\
\text { ratio } \pm \text { SD }^{*}\end{array}$ & $P$ value $^{\dagger}$ \\
\hline $\begin{array}{l}\text { Normal mucosa } \\
(\mathrm{n}=15)\end{array}$ & $78.68 \pm 7.96$ & $30.27 \pm 2.01$ & $26.35 \pm 20.07$ & $20.07 \pm 1.17$ & $0.515 \pm 0.132$ & \multirow{4}{*}{$<0.001$} \\
\hline $\begin{array}{l}\text { WD OSCC } \\
(\mathrm{n}=15)\end{array}$ & $123.03 \pm 6.91$ & $47.33 \pm 4.81$ & $60.32 \pm 32.89$ & $32.89 \pm 3.34$ & $0.965 \pm 0.271$ & \\
\hline $\begin{array}{l}\text { MD OSCC } \\
(\mathrm{n}=15)\end{array}$ & $134.18 \pm 8.45$ & $54.45 \pm 6.33$ & $66.00 \pm 39.45$ & $39.45 \pm 6.91$ & $0.971 \pm 0.164$ & \\
\hline $\begin{array}{l}\text { PD OSCC } \\
(\mathrm{n}=6)\end{array}$ & $156.02 \pm 12.39$ & $57.32 \pm 7.58$ & $74.66 \pm 43.87$ & $43.87 \pm 7.17$ & $1.018 \pm 0.353$ & \\
\hline
\end{tabular}

$C A=$ cellular area $S D=$ standard deviation; $C P=$ cellular perimeter $N A=$ nuclear area $N P=$ nuclear perimeter; $N / C=$ nuclear-to-cytoplasmic; $W D=$ well-differentiated $; O S C C$ = oral squamous cell carcinoma; $M D=$ moderately-differentiated; $P D=$ poorly-differentiated .

*Of both Feulgen-and $1 \%$ crystal violet-stained samples combined. ${ }^{\dagger}$ Using an analysis of variance test.

\section{Results}

In terms of MF assessment, all four phases of mitosis were visible in the samples, with prophase being the most difficult to detect [Figures $1 \mathrm{~A}$ and $\mathrm{B}$ ]. The most commonly seen phases of mitosis were metaphase, anaphase and telophase [Figures $1 \mathrm{C}$ and $\mathrm{D}$ and $2 \mathrm{~A}-\mathrm{D}]$. A few abnormal MFs, such as tripolar nuclei, were seen in various grades of OSCC using both stains [Figures 2E and F].

The frequency of MFs was significantly higher in the samples stained with Feulgen in comparison to $1 \%$ crystal violet $(3.51 \pm 2.93$ per field versus 2.47 \pm 2.47 per field; $P=0.050$ ) [Table 1]. The CA, CP, NA, NP and N/C ratio of the cells increased steadily from the normal gingival mucosa samples to the welldifferentiated and moderately-differentiated OSCC samples, before reaching their highest value in the poorly-differentiated OSCC samples, with statistically significant results $(P<0.001$ each $)$ [Table 2$]$.

\section{Discussion}

The Feulgen stain is a modified histochemical stain that is simple, cost-effective, reliable and allows for differentiation between apoptotic bodies, karyorrhexis and MFs, thereby excluding false-positive results. ${ }^{2,5,10,11}$ Furthermore, the purple-coloured chromatin material against a green cytoplasm facilitates the identification of MFs, even at lower magnifications. Multiple studies have reported using Feulgen staining to study nuclear and cellular morphometry and chromatin frameworks in oral cytosmears or paraffin-embedded tissue sections of various potentially malignant lesions, such as oral hyperplasia, dysplasia and OSCC..$^{6-8,14-18}$

In the present study, different mean mitotic counts were calculated using different stains, with a significantly greater frequency of MFs observed among samples stained with Feulgen stains compared to those stained with $1 \%$ crystal violet, regardless of OSCC grade. Similarly, Rao et al. also noted a significant increase in the number of MFs in Feulgenstained sections as compared to $1 \%$ crystal violetstained samples. ${ }^{10}$ A similar study by Palaskar et al. evaluating the effectiveness of $\mathrm{H} \& \mathrm{E}$, toluidine blue, Giemsa, crystal violet and Feulgen stains in oral epithelial dysplasia samples concluded that all of the aforementioned stains were useful in the identification of MFs, although Feulgen stains yielded superior results. ${ }^{19}$ In a study evaluating oral epithelial dysplasia and OSCC, Nikita et al. reported that Feulgen stains provided a greater contrast when staining MFs as compared to H\&E, toluidine blue, Giemsa and crystal violet stains; in addition, the MFs were easier to see at lower magnifications in comparison to the other stains. ${ }^{20}$

The current study also found a consistent increase in basal cellular and nuclear measurements beginning with the normal gingival mucosa samples and increasing with each grade of OSCC, thereby indicating heightened biological activity in the nucleus and cytoplasm. Nandini et al. proposed a new grading system for various nuclear features (NA, NP and nuclear form factor) based on their observations of a steady increase in all three features corresponding to increasing grades of OSCC in Feulgen-stained buccal mucosa samples. ${ }^{8}$ Similarly, Smitha et al. studied the nuclear and cellular morphometry of oral leukoplakia and OSCC cells in the basal layer using computeraided image analysis, concluding that the mean $\mathrm{CA}$, CP, NA and NP steadily increased from normal oral buccal mucosa to leukoplakia, reaching their highest values in OSCC cells. ${ }^{6}$

An increased $\mathrm{N} / \mathrm{C}$ ratio is a common feature of OSCC. ${ }^{21}$ As with the MF count and cellular and nuclear measurements, an increase in the $\mathrm{N} / \mathrm{C}$ ratio in the present study was also found to correlate with the OSCC grade. Shabana et al. likewise reported 
an increase in $\mathrm{N} / \mathrm{C}$ ratio to be consistent with the progression of oral lesions from a benign to malignant state.22 Similarly, another cytomorphometric analysis of oral lichen planus, oral submucous fibrosis, OSCC and normal oral mucosa indicated that the $\mathrm{N} / \mathrm{C}$ ratio was increased in potentially malignant lesions and OSCC cells. ${ }^{23}$

Based on the findings of the present study, it can be concluded that nuclear cytomorphometric parameters using computer-aided morphometry are a sophisticated tool to objectively assess and differentiate various grades of OSCC. As such, nuclear and cellular morphometric analysis can be utilised to quantitatively predict the rate of malignancy, thereby avoiding subjective errors and potentially informing treatment decisions. However, a prospective study involving a larger sample group should be performed in order to determine the validity and practicality of utilising such analyses for this purpose.

\section{Conclusion}

The authors strongly recommend the use of Feulgen stains for the distinct and selective staining of MFs. In addition, the authors further advise using computeraided morphometry to evaluate a combination of nuclear and cellular variables as a method of determining tumour aggressiveness.

\section{CONFLICT OF INTEREST}

The authors declare no conflicts of interest.

\section{FUNDING}

No funding was received for this study.

\section{References}

1. van Diest PJ, Brugal G, Baak JP. Proliferation markers in tumours: Interpretation and clinical value. J Clin Pathol 1998; 51:716-24. doi: 10.1136/jcp.51.10.716

2. Chinthu SK, Prasad H, Kumar GS, Mohan RM, Anuthama K, Yoithapprabhunath TR. Comparison of mitotic figures using haematoxylin \& eosin with crystal violet, toluidine blue, and Giemsa stain in oral epithelial dysplasia and in oral squamous cell carcinoma. BAOJ Dent 2016; 2:007. doi: 10.24947/baojd/2/1/107.

3. Kapoor K, Puri A, Prakash A, Jazib, Sharma G. Mitotic counting and its significance in histopathological grading of OSCC \& oral epithelial dysplasia. Heal Talk 2013; 5:35-7.

4. Tolbert PE, Shy CM, Allen JW. Micronuclei and other nuclear anomalies in buccal smears: Methods development. Mutat Res 1992; 271:69-77. doi: 10.1016/0165-1161(92)90033-I.

5. Jadhav KB, Ahmed Mujib BR, Gupta N. Crystal violet stain as a selective stain for the assessment of mitotic figures in oral epithelial dysplasia and oral squamous cell carcinoma. Indian J Pathol Micobiol 2012; 55:283-7. doi: 10.4103/0377-4929.101731.
6. Smitha T, Sharada P, Girish H. Morphometry of the basal cell layer of oral leukoplakia and oral squamous cell carcinoma using computer-aided image analysis. J Oral Maxillofac Pathol 2011; 15:26-33. doi: 10.4103/0973-029X.80034.

7. Christopher V, Murthy S, Sr A, Singh S, Cp A, Shivaram SK, et al. Morphometry as a diagnostic tool for potentially malignant lesions. J Clin Diagn Res 2015; 9:ZC22-5. doi: 10.7860/ JCDR/2015/15838.6959.

8. Nandini DB, Subramanyam RV. Nuclear features in oral squamous cell carcinoma: A computer-assisted microscopic study. J Oral Maxillofac Pathol 2011; 15:177-81. doi: 10.4103/ 0973-029X.84488.

9. Abdel-Salam M, Mayall BH, Hansen LS, Chew KL, Greenspan JS. Nuclear DNA analysis of oral hyperplasia and dysplasia using image cytometry. J Oral Pathol 1987; 16:431-5. doi: 10.1111/ j.1600-0714.1987.tb00713.x.

10. Rao RS, Patil S, Agarwal A. Comparison and evaluation of mitotic figures in oral epithelial dysplasia using crystal violet and Feulgen stain. J Contemp Dent Pract 2014; 3:273-7. doi: 10.50 05/jp-journals-10024-1527.

11. Ankle MR, Kale AD, Chandrimath S. Comparison of staining of mitotic figures by hematoxylin and eosin-crystal violet stains, in oral epithelial dysplasia and squamous cell carcinoma. Indian J Dent Res 2007; 18:101-5. doi: 10.4103/0970-9290.33784.

12. Bancroft JD, Gamble M, Eds. Theory and Practice of Histological Techniques, 5th ed. London, UK: Churchill Livingstone, 2001. Pp. 224-5.

13. Godkar PB, Godkar DP, Eds. Textbook of Medical Laboratory Technology: Clinical laboratory science and molecular diagnosis, 2nd ed. Mumbai, India: Bhalani Publishing House, 2005. Pp. 1009-11.

14. Gadiwan M, Madhushankari G, Mandana D, Praveen S, Selvamani M, Pradeep D. Nuclear features in different grades of epithelial dysplasia in leukoplakia: A computer assisted microscopic study. J Oral Maxillofac Pathol 2014; 18:194-200. doi: 10.4103/0973-029X.140747.

15. Hannen EJ, van der Laak JA, Manni JJ, Pahlplatz MM, Freihofer HP, Slootweg PJ, et al. An image analysis study on nuclear morphology in metastasized and non-metastasized squamous cell carcinomas of the tongue. J Pathol 1998; 185:175-83. doi: 10.1002/(SICI)1096-9896(199806)185:2<175::AID-PATH6 9>3.0.CO;2-U

16. Sharma D, Sandhu SV, Bansal H, Gupta S. Distinct perturbations of oral squamous cell carcinoma patients: A quantitative cytomorphometric analysis. Int J Health Sci (Qassim) 2015; 9:283-91.

17. Abdel-Salam $\mathrm{M}$, Mayall $\mathrm{BH}$, Chew $\mathrm{K}$, Silverman $\mathrm{S} \mathrm{Jr}$, Greenspan JS. Prediction of malignant transformation in oral epithelial lesions by image cytometry. Cancer 1988; 62:1981-7. doi: 10.1002/1097-0142(19881101)62:9<1981::AIDCNCR2820620918>3.0.CO;2-O.

18. Kasten FH. The Feulgen-deoxyribonucleic acid absorption curve in normal and tumorous tissues. J Histochem Cytochem 1957; 5:398-402. doi: 10.1177/5.4.398

19. Palaskar SJ, Patil S, Narang B, Prabhu P, Kathuriya P, Pawar R. Efficacy of various stains to study mitotic figures in oral epithelial dysplasia: A pilot study. J Dent Allied Sci 2013; 2:46-8. doi: $10.4103 / 2277-4696.159281$

20. Nikita G, Navneet KB, Akanksha B, Maiunita B, Devi CS, Ajit R. Abstract: Special stains to highlight mitotic figures in oral epithelial dysplasia and squamous cell carcinoma. J Oral Maxillofacial Pathol 2014; 18:S17.

21. Shilpi, Chandra S, Samadi FM, Sreedhar G, George J, Thippeswamy SH. Comparison of morphometric parameters in suprabasal cells in epithelial hyperplasia, leukoplakia and squamous cell carcinoma: An image analysis. Int J Contemp Med Res 2016; 3:2307-9. 
Evaluation of Mitotic Figures and Cellular and Nuclear Morphometry of Various Histopathological Grades of Oral

22. Shabana AH, el-Labban NG, Lee KW. Morphometric analysis of basal cell layer in oral premalignant white lesions and squamous cell carcinoma. J Clin Pathol 1987; 40:454-8. doi: $10.1136 /$ jcp.40.4.454
23. Hegde V. Cytomorphometric analysis of squames from oral premalignant and malignant lesions. J Clin Exp Dent 2011; 5:e441-4. doi: 10.4317/jced.3.e441. 